\title{
Morphological and Molecular Identification of four Brazilian Commercial Isolates of Pleurotus spp. and Cultivation on Corncob
}

\author{
Nelson Menolli Junior ${ }^{1,2^{*}}$, Tatiane Asai ${ }^{1}$, Marina Capelari ${ }^{1}$ and Luzia Doretto Paccola- \\ Meirelles $^{3}$ \\ ${ }^{1}$ Instituto de Botânica; Núcleo de Pesquisa em Micologia; C. P. 3005; 01061-970; São Paulo - SP - Brasil. \\ ${ }^{2}$ Instituto Federal de Educação, Ciência e Tecnologia; Rua Pedro Vicente 625; Canindé; 01109-010; São Paulo - \\ SP - Brasil. ${ }^{3}$ Universidade Estadual de Londrina; Departamento de Biologia Geral; C. P. 6001; 86051-990; \\ Londrina - PR - Brasil
}

\begin{abstract}
The species of Pleurotus have great commercial importance and adaptability for growth and fructification within a wide variety of agro-industrial lignocellulosic wastes. In this study, two substrates prepared from ground corncobs supplemented with rice bran and charcoal were tested for mycelium growth kinetics in test tubes and for the cultivation of four Pleurotus commercial isolates in polypropylene bags. The identification of the isolates was based on the morphology of the basidiomata obtained and on sequencing of the LSU rDNA gene. Three isolates were identified as P. ostreatus, and one was identified as P. djamor. All isolates had better in-depth mycelium development in the charcoal-supplemented substrate. In the cultivation experiment, the isolates reacted differently to the two substrates. One isolate showed particularly high growth on the substrate containing charcoal.
\end{abstract}

Key words: charcoal, edible mushroom cultivation, molecular analysis, taxonomy

\section{INTRODUCTION}

The genus Pleurotus (Fr.) P. Kumm comprises various edible mushroom species and has important medical and biotechnological properties and environmental applications (Cohen et al., 2002). Pleurotus species present high adaptability for growth and fructification within a wide variety of agro-industrial lignocellulosic wastes due to their production of lignolytic and hydrolytic enzymes (Mikiashvili et al., 2006).

Any lignocellulosic waste can be used for Pleurotus cultivation, and many have been tested: sugarcane bagasse, banana skins, corn residues, grass, sawdust, rice and wheat straw, banana leaves, paper and cardboard. In addition, supplements like wheat, soybeans, oat and rice bran are widely employed to enrich the basic substrate for cultivation of mushrooms (Dias et al., 2003; Donini et al., 2006; Maki and PaccolaMeirelles, 2002; Mandeel et al., 2005; Moda et al., 2005; Ruegger et al., 2001). Corncobs are one widely available agricultural waste in Paraná State, Brazil, because this state is the biggest corn producer in Brazil (Duarte, 2007). This waste is usually either burned or left on the crop fields to

*Author for correspondence: menollijr@yahoo.com.br 
be incorporated into the soil, so its utilization in mushroom production would be appropriate.

Commercial mushroom cultivation demands good control of temperature, humidity and luminosity conditions. Thus, reducing the time required for the culture cycle is necessary to decrease production costs. Therefore, methods that increase either mycelium growth or fructification are of interest. Some chemical products have been used to increase mycelium growth of some species of mushrooms. For example, sulfonated monosaccharides induce mycelium growth in Flammulina velutipes (Curtis) Singer, Lentinula edodes (Berk.) Pegler and Pleurotus ostreatus (Jacq.) P. Kumm (Inaba et al., 1983), and veratryl alcohol stimulates the fructification of $P$. ostreatus (Suguimoto et al., 2001) even though there are no reports about the utilization of these compounds in the mushroom industry.

One purpose of this study is to verify the viability of corncob utilization for the production of commercial strains of Pleurotus spp. and to determine the effect of the addition of charcoal to the cultivation substrate.

The taxonomy of Pleurotus species, despite all efforts to clarify it, remains confusing. Kirk et al. (2008) recognize 20 species for the genus, although other authors have recognized 30 to 40 species (Hilber, 1982; Singer, 1986). The plasticity of basidioma morphology of various species, especially those distributed in different regions of the world, as well as the erroneous identification of commercial isolates has led to multiple names for the same species, perpetuating identification errors (Buchanan, 1993).

Today, the combination of morphological studies and molecular phylogenetic analysis provides a good tool to understand the systematics and species boundaries in Pleurotus. Phylogenies based on the coding genes of the ribosomal DNA strongly support several taxonomic groups within the genus (Vilgalys et al., 1996; Vilgalys and Sun, 1994a; Zervakis et al., 2004). Accordingly, the second aim of this study was to assign the isolates to the correct species using morphology and rDNA sequences to start facilitating the identification of commercial isolates or other isolates of unknown origin.

\section{MATERIALS AND METHODS}

\section{Isolates}

Four Pleurotus isolates were selected from the strain bank of the "Laboratório de Genética de Microrganismos" of the Universidade Estadual de Londrina (Londrina, PR, Brazil). Three of the strains (Pt I, Pt II and Pt III) were obtained from cultivators, and one (CCB 001) was obtained from the "Coleção de Cultura de Basidiomicetos" of the Instituto de Botânica (São Paulo, SP, Brazil), stored at ATCC (American Type Culture Collection) as Pleurotus ostreatus var. florida (ATCC 96997).

\section{Substrates tested}

The substrates employed in the production and indepth mycelium development assessments of Pleurotus were prepared with ground corncob, adjusted to $65 \%$ water content, and supplemented with rice bran, calcium carbonate $\left(\mathrm{CaCO}_{3}\right)$ and charcoal in two treatments according to Table 1.

Table 1 - Substrates tested for the production and in-depth mycelium development of Pleurotus isolates.

\begin{tabular}{ll}
\hline Treatments & \multicolumn{1}{c}{ Composition } \\
\hline S1 & Corncob $+20 \%$ rice bran $+1 \% \mathrm{CaCO}_{3}$ \\
S2 & Corncob $+20 \%$ rice bran $+1 \% \mathrm{CaCO}_{3}+10 \%$ charcoal \\
\hline
\end{tabular}

\section{In-depth mycelium development assessments} The selected isolates underwent in-depth growth assessments in two basic treatments (S1 and $\mathrm{S} 2)$. Test tubes of $55 \mathrm{ml}$ volume $(14.2 \times 2.2 \mathrm{~cm}-$ depth $\times$ diameter) were filled with $20 \mathrm{~g}$ of substrate and, after slight compaction, autoclaved for one hour at $121^{\circ} \mathrm{C}(1 \mathrm{~atm})$. Afterwards, a $10-\mathrm{mm}$ diameter mycelium disc, obtained from a seven-day culture, was inoculated in the central region of each tube. The tubes were incubated at $25^{\circ} \mathrm{C}$ in the dark. After the third day of incubation, the growth was monitored every 48 hours, until complete colonization. Ten replicates for each isolate and substrate were made, and the experimental design was fully randomized. 


\section{Production assessment on sterile substrates Spawn and substrate preparation}

Untreated wheat seeds, previously hydrated in distilled water for 12 hours, were put into $500-\mathrm{ml}$ glass flasks (which were transparent and cylindrical). The flasks were closed with stoppers that were perforated in the middle, sealed with micropore tape to allow gaseous exchange, and then autoclaved for one hour at $121^{\circ} \mathrm{C}$. Mycelium discs (10-mm diameter) were inoculated into the wheat seed substrate. The flasks were incubated at $25^{\circ} \mathrm{C}$ in the dark for 25 days, the period necessary for complete colonization.

Approximately $600 \mathrm{~g}$ of each corncob substrate was put in heat resistant polypropylene bags and, after slight compaction, autoclaved for one hour at $121^{\circ} \mathrm{C}$. Afterwards, $10 \mathrm{~g}$ of the Pleurotus spawn was added to the bags and incubated at approximately $25^{\circ} \mathrm{C}$ in a room exposed to daylight. Each treatment was composed of 10 replicates of three samples each. The experiment was designed in randomized blocks.

\section{Fructification induction}

After complete substrate colonization, 21 rectangular holes $(2.5 \times 4.4 \mathrm{~cm})$ were made across portion of the bag that was in contact with the substrate, taking care not to demage the mycelia. After the beginning of fructification, the air humidity was maintained with a vaporizer. The substrates in the bags were sprinkled daily, maintaining relative humidity at around $85 \%$.

\section{Assessment}

After fructification, the basidiomata were collected, weighted when fresh and then dehydrated to determine the dry mass. The cultivation substrates were maintained until no more mushrooms were produced.

The parameters employed to assess productivity were mushroom fresh mass, mushroom dry mass, productivity $(\mathrm{P})$, and biological efficiency (BE). Both productivity and biological efficiency were expressed in percent rates and calculated using the following formulas:

$\mathrm{P}=\frac{\text { mushroom dry mass }}{\text { dry mass of initial substrate }} \times 100$

$\mathrm{BE}=\frac{\text { mushroom fresh mass }}{\text { dry mass of initial substrate }} \times 100$

\section{Morphological studies}

The macroscopic characteristics of the basidiomata collected from each isolate were recorded, according to Largent (1977). Vouchers were deposited at the Herbário do Estado Maria Eneyda P. Kaufmann Fidalgo (SP) under the following accession numbers: SP392847 (for Pt II), SP392848 (for CCB001), SP392849 (for Pt III) and SP392850 (for Pt IV). For microscopic analysis, the dry material was rehydrated in $70 \%$ ethanol followed by either 5\% KOH or Melzer's reagent, according to Largent et al. (1977). All microscopic illustrations were made with the aid of a drawing tube. For the morphological identifications, Singer (1961, 1986), Pegler (1977a, b, 1997), Corner (1981), Hilber (1982, 1997), Guzmán et al. (1993) and Lechner et al. (2004) were consulted.

\section{Molecular studies \\ DNA extraction}

The isolates were inoculated into potato dextrose liquid culture medium. The mycelia obtained were filtered, lyophilized and grounded to a fine powder in liquid nitrogen. DNA was extracted by adding approximately $0.5 \mathrm{~g}$ of the sample to extraction buffer solution according to the method of Ferreira and Grattapaglia (1996). The DNA samples were resuspended in $50 \mu \mathrm{l}$ TE. Afterwards, $2 \mu \mathrm{l}$ of RNAse was added to each sample, and the samples were incubated at $37^{\circ} \mathrm{C}$ for $30 \mathrm{~min}$ and then stored at $-20^{\circ} \mathrm{C}$.

DNA amplification and sequencing

Partial sequences of the nLSU gene, containing rRNA coding regions, were amplified using the primers LR0R (5'-ACCCGCTGAACTTAAGC3') and LR16 (5'-TTCCACCCAAACACTCG-3'). Additional information about these primers is given at http://www.biology.duke.edu/fungi/ mycolab/primers.htm. The region was amplified in $100 \mu \mathrm{L}$ PCR reactions containing $2.5 \mathrm{U}$ Platinum $^{\mathrm{TM}}$ Taq DNA Polymerase (Invitrogen), $0.2 \mathrm{mM}$ of each dNTP, $1.5 \mathrm{mM} \mathrm{MgCl} 2$ and $0.2 \mu \mathrm{M}$ of each primer.

PCR was performed in an Eppendorf thermocycler using the following program: $94^{\circ} \mathrm{C}$ for $5 \mathrm{~min}, 40$ cycles at $94^{\circ} \mathrm{C}$ for $40 \mathrm{~s}, 55^{\circ} \mathrm{C}$ for $30 \mathrm{~s}$ and $72^{\circ} \mathrm{C}$ for $1 \mathrm{~min}$, and a final elongation at $72^{\circ} \mathrm{C}$ for $5 \mathrm{~min}$. The amplicons were directly purified from the reactions using the PureLink ${ }^{\mathrm{TM}}$ PCR Purification Kit (Invitrogen). The purified amplification products were sequenced on a MegaBace 1000 automated sequencer (Molecular Dynamics) using the DYEnamic ET dye terminator cycle sequencing kit. The amplicons were sequenced in both directions using the same primers used for 
amplications, and the consensus sequences were generated using the Phred/Phrap/Consed software. The sequences have been deposited in GenBank.

Sequence analysis

The partial nLSU sequences generated in this study plus ten sequences obtained from the GenBank (Table 2) were aligned using Clustal W (Thompson et al., 1994). The GenBank sequences utilized in our analysis came from isolates studied by Vilgalys et al. (1996) and Vilgalys and Sun (1994a). Characters from the extreme 5' and 3' ends were excluded from all taxa to obtain datasets that had identical start and end positions. Gaps were treated as missing data. PAUP v.4.0b10 (Swofford, 2003) was used to generate maximum parsimony trees by a heuristic search with simple sequence addition. The confidence levels of the branches were estimated using 1,000 bootstrap replicates. The generated trees were rooted using Hohenbuehelia mastrucata (Fr.) Singer and H. grisea (Peck) Singer as outgroup taxa.

Table 2 - Collection data and GenBank accession numbers of the sequences used in the molecular analyses.

\begin{tabular}{lccc}
\hline \multicolumn{1}{c}{ Species } & Culture/herbarium number & Origin & GenBank accession number \\
\hline Hohenbuehelia mastrucata & $\mathrm{T}-025$ & Canada & EF409736 \\
H. grisea & RGT $010805 / 02$ & Costa Rica & EF409760 \\
Pleurotus euosmus & CCRC 36212 & - & AY265826 \\
P. flabellatus & ATCC 38140 & - & AY368660 \\
P. djamor & $\mathrm{d} 8$ & China & AY524785 \\
P. djamor & $\mathrm{Pt}$ IV / SP392850 & - & EU165505 \\
P. djamor & $\mathrm{D} 1829^{\mathrm{a}}$ & Malaysia & $\mathrm{U} 04138$ \\
P. djamor & $\mathrm{D} 1847^{\mathrm{a}}$ & Mexico & $\mathrm{U} 04139$ \\
P. ostreatus & $\mathrm{D} 331^{\mathrm{a}}$ & Czech Republic & $\mathrm{U} 04143$ \\
P. ostreatus & $\mathrm{Pt}$ II $/ \mathrm{SP} 392847$ & - & EU165507 \\
P. ostreatus & $\mathrm{CCB} 001 / \mathrm{SP} 392848$ & - & EU165506 \\
P. ostreatus & $\mathrm{Pt} \mathrm{III} / \mathrm{SP} 392849$ & - & EU165508 \\
P. pulmonarius & $\mathrm{D} 479^{\mathrm{a}}$ & Germany & $\mathrm{U} 04151$ \\
P. salmoneostramineus & $\mathrm{ASI} 2172$ & - & AY265845 \\
\hline
\end{tabular}

${ }^{a}$ Vilgalys et al. (1996); Vilgalys and Sun (1994a).

\section{RESULTS AND DISCUSSION}

\section{In-depth mycelium development}

Mycelium growth was observed until the 13th day of incubation when at least one of the four isolates had completely colonized the substrate in the test tube.

At the concentration utilized, charcoal significantly stimulated mycelium growth in all four strains (Table 3). Fast colonization is commonly seen as a positive factor for mushroom propagation. However, colonization speed does not always guarantee good productivity.

The agricultural utilization of charcoal by-products is promising. They have long been used in Japan and have recently been introduced in Brazil (Zanetti et al., 2003). The porosity of charcoal may increase the substrate porosity, thus improving water retention and facilitating aeration of the compound. These factors, essential to mushroom colonization, seem to have stimulated mycelium growth of the isolates.

Table 3 - In-depth mycelium development average ( $\mathrm{mm})$ of Pleurotus isolates on the 13th day of incubation in two substrates: S1 and S2 (see Table 1).

\begin{tabular}{ccccc}
\hline \multirow{2}{*}{ Substrates } & \multicolumn{4}{c}{ Pleurotus isolates } \\
\cline { 2 - 5 } & CCB001 & Pt II & Pt III & Pt IV \\
\hline S1 & $78.9 \pm 5.9 \mathrm{bB}$ & $78.9 \pm 4.5 \mathrm{bB}$ & $82.2 \pm 3.3 \mathrm{bA}$ & $81.4 \pm 3.0 \mathrm{bAB}$ \\
S2 & $89.4 \pm 2.8 \mathrm{aB}$ & $94.3 \pm 1.6 \mathrm{aA}$ & $94.8 \pm 0.6 \mathrm{aA}$ & $94.6 \pm 1.6 \mathrm{aA}$ \\
\hline
\end{tabular}

Means followed by the same letter (lower case within columns and upper case within rows) are not significantly different at the $5 \%$ probability level according to Tukey tests. 


\section{Production on sterile substrate}

Mycelia running through the substrate could be observed from the third day after spawn addition, and the isolates reacted differently according to the substrate. Different effects in development of isolates have also been reported by Mandeel et al. (2005) and Dias et al. (2003) in studies of the interaction between Pleurotus isolates and substrate components.

Isolate CCB001 did not develop basidiomata under the experimental conditions. Therefore, it was not considered further in the production experiments. The colonization period for Pt II and Pt IV was shorter in the substrate supplemented with charcoal demonstrating, as observed in the test tubes, that the addition of charcoal has a positive effect on mycelium development during the colonization period. This effect was not observed for Pt III when colonizing the substrate on a production scale even though the colonization period in test tubes was significantly shorter for this isolate in the substrate supplemented with charcoal.

The highest production was obtained with Pt II in the substrate supplemented with charcoal. The fresh and dry masses of mushrooms produced by Pt II in S2 were higher, and consequently BE and $P$ were greater (Table 4). The addition of charcoal to the substrate did not affect the production of $\mathrm{Pt}$ IV. The addition of charcoal resulted in an increase of $\mathrm{P}$ and dry mass of mushrooms produced by Pt III; however, no changes in $\mathrm{BE}$ and fresh mass of mushrooms were observed. Perhaps the addition of charcoal influenced the water uptake of mushrooms produced by isolate Pt III.

Table 4 - Colonization and production average of Pleurotus isolates in two substrates: S1 and S2 (see Table 1).

\begin{tabular}{lccc}
\hline \multirow{2}{*}{ Parameters evaluated } & \multicolumn{3}{c}{ Isolates } \\
\cline { 2 - 4 } & Pt II & Pt III & Pt IV \\
\hline Colonization time (days) & 25 & & \\
S1 & 20 & 25 & 19 \\
S2 & & 30 & \\
\hline Mushroom Fresh Matter (g) & $34.57 \pm 13.5 \mathrm{bB}$ & $48.35 \pm 9.1 \mathrm{aA}$ & $53.46 \pm 9.3 \mathrm{aA}$ \\
S1 & $58.40 \pm 21.4 \mathrm{aA}$ & $49.99 \pm 13.7 \mathrm{aA}$ & $50.65 \pm 11.6 \mathrm{aA}$ \\
S2 & & & \\
Mushroom Dry Matter (g) & $6.75 \pm 2.3 \mathrm{bA}$ & $8.12 \pm 1.1 \mathrm{bA}$ & $8.05 \pm 1.2 \mathrm{aA}$ \\
S1 & $9.02 \pm 2.5 \mathrm{aAB}$ & $10.37 \pm 2.0 \mathrm{aA}$ & $7.96 \pm 1.1 \mathrm{aB}$ \\
S2 & & & \\
\hline Biological Efficiency (\%) & $16.08 \pm 6.3 \mathrm{bB}$ & $22.79 \pm 4.3 \mathrm{aA}$ & $24.86 \pm 4.3 \mathrm{aA}$ \\
S1 & $27.16 \pm 9.9 \mathrm{aA}$ & $23.25 \pm 6.4 \mathrm{aA}$ & $23.56 \pm 5.4 \mathrm{aA}$ \\
S2 & & & \\
Productivity (\%) & $3.14 \pm 1.1 \mathrm{bA}$ & $3.78 \pm 0.5 \mathrm{bA}$ & $3.75 \pm 0.6 \mathrm{aA}$ \\
S1 & $4.20 \pm 1.2 \mathrm{aAB}$ & $4.83 \pm 0.9 \mathrm{aA}$ & $3.70 \pm 0.5 \mathrm{aB}$ \\
S2
\end{tabular}

Means followed by the same letter (lower case within columns and upper case within rows) are not significantly different at the $5 \%$ probability level according to Tukey tests

The results herein obtained for corncob substrates, demonstrate $\mathrm{BE}$ values smaller than those recorded in the literature for other substrates like bean straw, corn and coffee husk (Dias et al., 2003). Sturion and Oetterer (1995) have evaluated the BE of several substrates for production of Pleurotus sajor-caju (Fr.) Singer. Among the tested materials, banana straw resulted in a BE of $50.33 \%$ but when corncob was added the BE decreased to $19.15 \%$. Colauto and Eira (1995) have obtained a BE of $39.9 \%$ with the same species on a substrate of sugarcane bagasse and beanstalk straw.

A factor that probably contributes to these results is the fact that corncob is poor in nutrients, especially when the corncobs utilized come from poor or unmanured soils. Corncob is mainly a source of cellulose, hemicellulose and lignin. Therefore, enrichment of corncob substrate with other nutrients is highly recommended. Supplementation of the substrate with either mineral or organic nutrients could help to improve 
the BE. Carbon sources, among others nutrients that increase the availability of carbohydrates, can increase the production of lignolytic enzymes to contribute to a satisfactory fungal growth and final biomass accumulation (Mikiashvili et al., 2006). The charcoal added to the substrate in our experiment may have increased the production of enzymes to result in greater P for Pt II and Pt III, and greater BE for Pt II.

As demonstrated, the addition of charcoal to the substrate improved the production of Pleurotus, although the results are dependent of the isolate tested. Charcoal is also fundamental for the mushroom production of Macrolepiota bonaerensis (Speg.) Singer when it is added to casing soil, as shown by Maki and PaccolaMeirelles (2002).

Others supplements may increase the productivity of the substrate. Dias et al. (2003) have observed significant improvement associated with the supplementation of corn straw with wheat flour, gypsum and calcium carbonate, and Moda et al. (2005) have obtained increased BE for $P$. sajor-caju on sugarcane bagasse substrates supplemented with mineral nutrients.

\section{Taxonomy}

Based on morphological and molecular data, the basidiomata of Pt IV were identified as $P$. djamor (Rumph. ex Fr.) Boedijn, and those of Pt II, Pt III and CCB 001 as P. ostreatus.

Pleurotus djamor (Rumph. ex Fr.) Boedijn, Wit, H.C.D. de, Ed., Rumphius Memorial v.292. 1959.

(Fig. 1)

Pileus $70-100(-130) \times 55-85(-100) \mathrm{mm}$, spatulate to flabelliform, pinkish when fresh, cream or yellowish when dry, surface smooth, margin smooth. Stipe absent or reduced, (5-)10$20 \times 4-8(-10) \mathrm{mm}$, lateral, sometimes eccentric, cream to light pink, surface smooth. Lamella decurrent, concolorous with the stipe, edge smooth, lamellulae present. Spore print pink becoming white or light yellowish when dry. Basidiospores (8.7-)10.0-11.2 × 3.7-5.0 $\mu \mathrm{m}$, cylindrical, thin-walled, hyaline, smooth, inamyloid. Basidia 25-26 × 5.0-6.2(-7.5) $\mu \mathrm{m}$, clavate, four-spored, sometimes two- or threespored. Basidioles numerous. Pleurocystidia not observed. Cheilocystidia (18.7-)21-26 × 6.2$10.0(-11.2) \mu \mathrm{m}$, subventricose to clavate.
Lamellar trama irregular, 50-62 $\mu \mathrm{m}$ wide, composed of thick- or thin-walled hyphae, hyaline, septate, with clamps, $3.7 \mu \mathrm{m}$ diam. Subhymenium cellular well differentiated, up to $18.7 \mu \mathrm{m}$ width. Pileus context undifferentiated, composed of thick-walled hyphae, septate, with clamps, 3.7-6.2 $\mu \mathrm{m}$ diam. Pileipellis undifferentiated.

Material examined: unknown origin, commercial isolate, basidiomata produced on corncob substrate, 3-III-2007, Menolli Jr. 144 (SP).

Comments: This species has been described several times and has many synonyms published. It shows great phenotypic plasticity, mainly in pileus color, which ranges from deep pink salmon to slightly pinkish and even white. It belongs to intersterility group ISG 5 (Vilgalys and Sun, 1994b) and is widely distributed around the world. In Pleurotus, at least five species from distinct geographical localities present salmon-pinkish colored basidiomata: P. ëous (Berk.) Sacc. (Pegler, 1977a; Saccardo, 1887), P. flabellatus (Berk. and Broome) Sacc. (Pegler, 1977b; Saccardo, 1887), P. ostreatoroseus Singer (Pegler, 1997; Singer, 1961), P. salmoneostramineus Lj.N.Vassiljeva (Guzmán et al., 1995), and P. djamor (Rumph. ex Fr.) Boedijn (Corner, 1981; Guzmán et al., 1993). Corner (1981) has recognized six varieties of $P$. djamor based on differences in pileus and lamellae color, shape of stipe, and substrate. However, in the literature the nomenclature of these varieties is highly confused.

According to Guzmán et al. (1993), $P$. ostreatoroseus, described from Brazil, is related to $P$. djamor var. fuscoroseus Corner and $P$. djamor var. roseus Corner, both from Singapore [the latter has also been reported from Brazil (Corner, 1981)], and to P. salmoneostramineus (Hongo, 1973) from Japan. Neda et al. (1988) have demonstrated intercompatibility between $P$. salmoneostramineus and $P$. djamor, and Murakami and Takemaru (1990) have obtained white basidiomata of $P$. salmoneostramineus and have suggested that color differences do not justify the separation of $P$. salmoneostramineus and P. djamor, or P. djamor var. roseus. Guzmán et al. (1993) further claim that some Mexican materials of $P$. djamor var. djamor, according to Corner's (1981) classification are probably $P$. djamor var. roseus, or they may represent intermediate forms between these two varieties. 


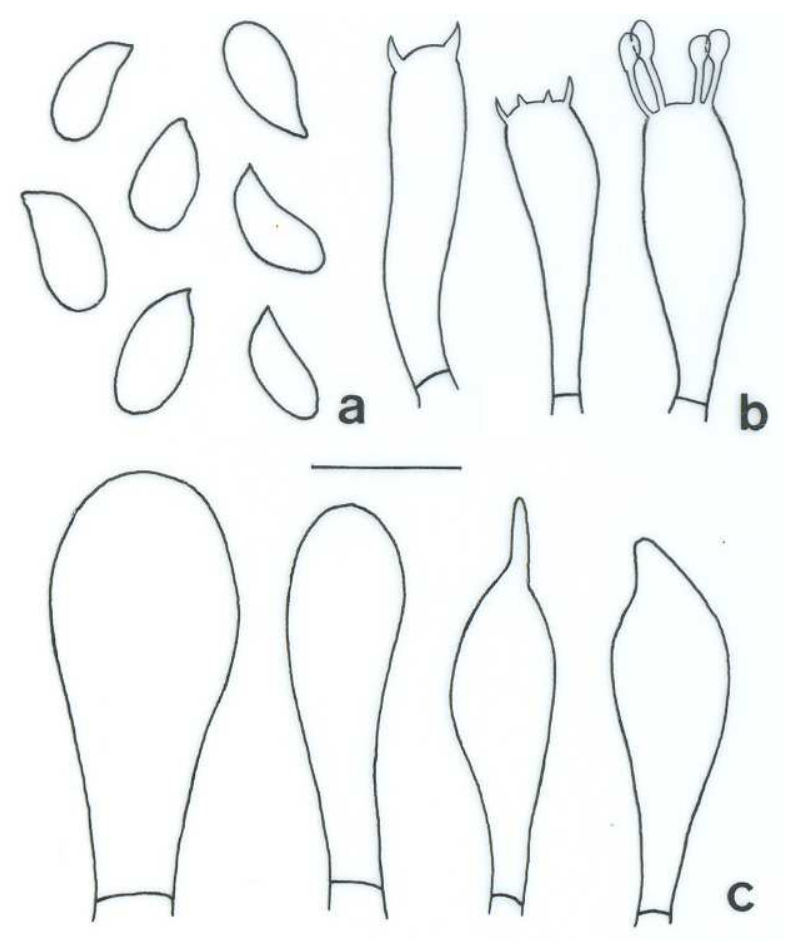

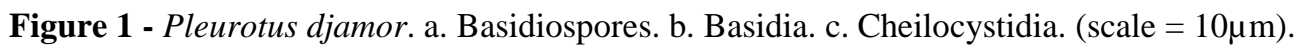

Corner (1981) claims that $P$. ëous, as described by Pegler (1972), is probably the same fungus as P. djamor var. roseus. Hilber (1997) includes $P$. salmoneostramineus, $P$. ostreatoroseus and $P$. flabellatus in the synonymy of $P$. ëous. Pleurotus flabellatus was considered a valid species by Pegler $(1977 \mathrm{a}$, b) but it has been considered a synonym of $P$. djamor by Corner (1981), Guzmán et al. (1993) and Pegler (1986).

Pleurotus ostreatus (Jacq.) P. Kumm., Führer der Pilzkunde (Zwickau): 105. 1871.

(Fig. 2)

Pileus 45-65 $(-110) \times 25-85 \mathrm{~mm}$, slightly infundibuliform, white, cream or grayish, in some cases dark gray when young, surface smooth, margin smooth or occasionally lobate. Stipe 22-32 $\times 8 \mathrm{~mm}$, lateral-eccentric, cream, surface smooth. Lamella decurrent, concolorous with the stipe, edge smooth, lamellulae present. Spore print white to creamy-grayish.

Basidiospores 8.7-11.2 × $3.7 \mu \mathrm{m}$, cylindrical, thin-walled, hyaline, smooth, inamyloid. Basidia (18.7-)20-22(-26) × (3.7-)5.0-7.5 $\mu \mathrm{m}$, clavate, four-spored. Basidioles numerous. Pleurocystidia not observed. Cheilocystidia (12.5-) 17.5-24(-29) $\times \quad(3.7-) 5.0-6.2(-7.5) \quad \mu \mathrm{m}, \quad$ subventricose, ventricose or subclavate. Lamellar trama irregular, 66-87 $\mu \mathrm{m}$ wide, composed of thick- or thin-walled hyphae, hyaline, septate, with clamps, 3.7-5.0 $\mu \mathrm{m}$ diam. Pileus context undifferentiated, composed of thick-walled hyphae, with clamps, 3.7-6.2 $\mu \mathrm{m}$ diam. Pileipellis undifferentiated.

Material examined: unknown origin, commercial isolates, basidiomata produced on corncob and sugarcane substrates, 3-VII-1998, Capelari s.n. (SP392848); 3-III-2007, Menolli Jr. 145 (SP); 3-III-2007, Menolli Jr. 146 (SP).

Comments: For P. ostreatus, as well as for other species of the genus, there are some nomenclatural difficulties, especially regarding the relationship of $P$. ostreatus to $P$. pulmonarius (Fr.) Quél. Intercompatibility studies performed by Petersen and Hughes (1993) and Hilber (1982) confirm the separation into two biological species (IGS I and IGS II, respectively). To complement the type description and trying to solve some taxonomic problems of $P$. ostreatus, Petersen and KrisaiGreilhuber (1996) have designated an epitype of $P$. ostreatus with a collection from the type locality (Austria).

Despite the overlap in pileus color, the main morphological distinction between these species is the presence of cheilocystidia in P. ostreatus, as confirmed in the epitype and the absence of these structures in P. pulmonarius (Petersen and KrisaiGreilhuber, 1996). However, previous descriptions 
of $P$. ostreatus did not mention the presence of cheilocystidia (Bresinsky et al., 1987; Hilber, 1982; Lechner et al., 2004; Zervakis and Balis, 1996) and attributed white, cream or light brown colors mainly to North American materials (Hilber, 1997; Petersen and Hughes, 1993).

Pleurotus pulmonarius is often characterized by pileus color pale ochre, light brown, yellowish brown, or with violet shades, becoming yellowish in maturity or when dry, and by the absence of cheilocystidia (Buchanan, 1993; Hilber, 1982; Hrouda, 2001; Petersen and Hughes 1993). However, Hilber (1997) described white and gray colors for basidiomata, and Segedin et al. (1995) have observed the presence of cheilocystidia in a specimen identified as $P$. pulmonarius and collected in New Zealand, which, according to the description presented, could probably be referred to $P$. ostreatus instead of $P$. pulmonarius.

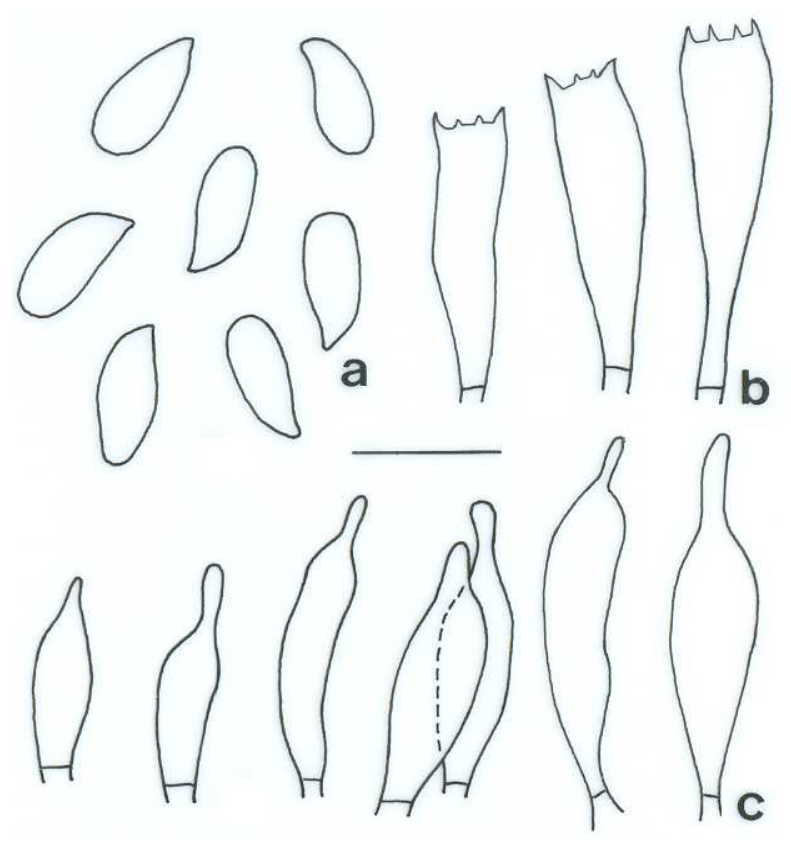

Figure 2 - Pleurotus ostreatus. a. Basidiospores. b. Basidia. c. Cheilocystidia. $($ scale $=10 \mu \mathrm{m})$.

The nomenclatural problems of $P$. ostreatus also involve $P$. florida Eger (nom. nud.), which has a large commercial distribution but is now accepted as $P$. ostreatus (Hilber, 1997). Intercompatibility studies involving P. ostreatus and P. florida have shown compatibility between all isolates studied by Eger et al. (1976). However, Hilber (1982) has reported the compatibility of an isolate of $P$. florida with $P$. pulmonarius, as well as the incompatibility of this isolate with $P$. ostreatus, and also the compatibility of another P. florida isolate with $P$. ostreatus and the incompatibility of this latter isolate with $P$. pulmonarius. Such $P$. florida isolates must actually be either $P$. ostreatus or $P$. pulmonarius isolates distributed under the wrong denomination by mushroom producers, since no $P$. florida isolate compatible with both $P$. pulmonarius and $P$. ostreatus has been reported (Bresinsky et al., 1987).
Intercompatibility studies (M. Capelari, unpublished data) of the isolate CCB001 show partial compatibility with $P$. ostreatus (URM328, Micoteca from the Universidade Federal de Pernambuco) and with $P$. columbinus Quél. (MUCL 28154, Belgian Co-ordinated Collections of Micro-organisms), which has been synonymized under P. ostreatus (Hilber, 1997). These data confirm the biological identity of CCB001 as $P$. ostreatus, which shares similar morphological characteristics, including the presence of cheilocystidia, with Pt II and Pt III.

\section{Molecular analysis}

The molecular analysis of the nLSU gene shows a well-supported clade with $98 \%$ bootstrap support including all Pleurotus species analyzed. This clade is further divided into two subclades (Fig. 3). 


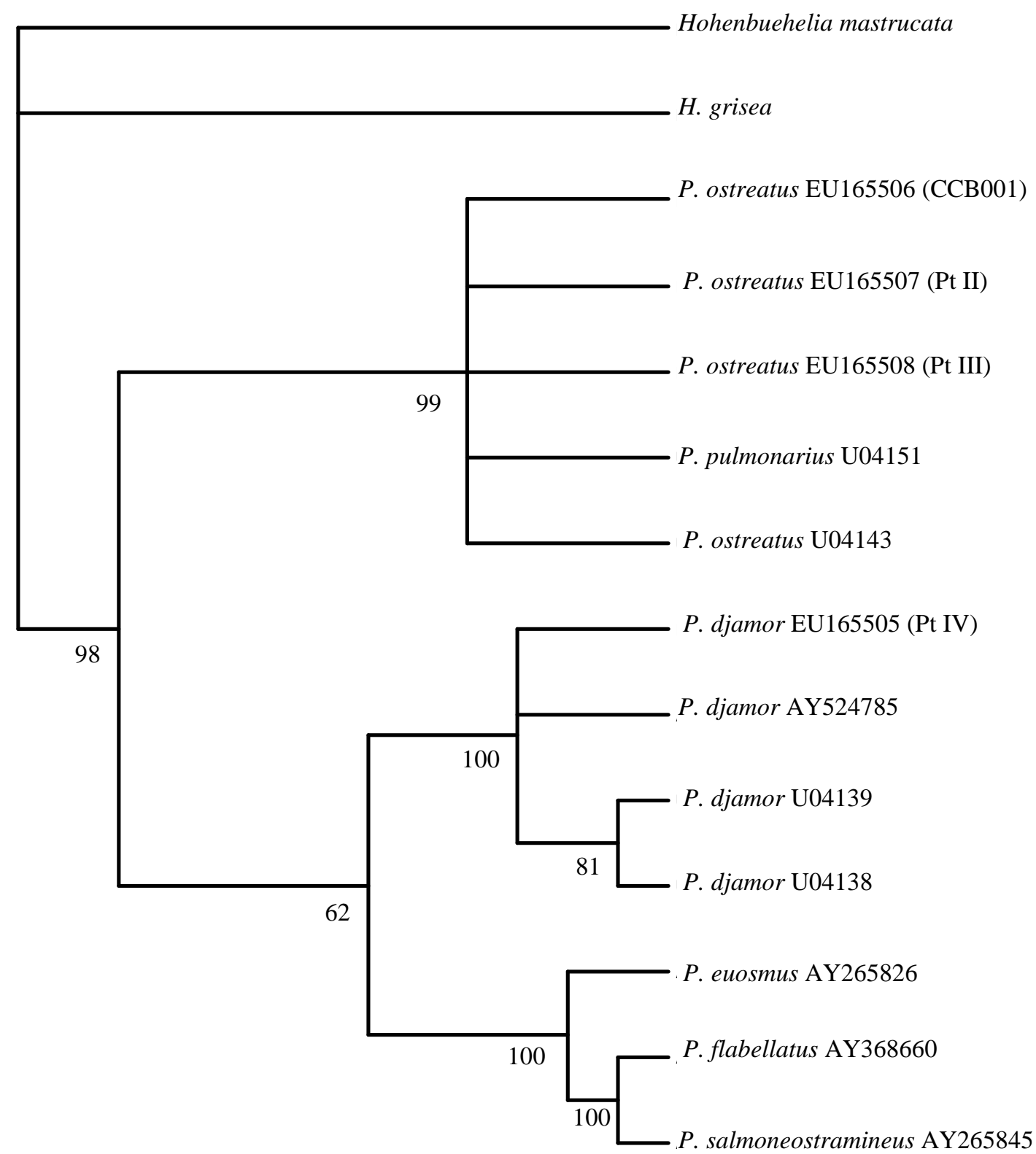

Figure 3 - Cladogram generated by parsimony analysis of the partial nLSU rDNA sequences. The tree is rooted using Hohenbuehelia mastrucata and H. grisea as outgroups. Bootstrap numbers are shown below the nodes.

The sequences from the isolates Pt II, Pt III and CCB001, identified as $P$. ostreatus, cluster in one clade with $99 \%$ support along with two other sequences from GenBank, P. ostreatus (U04143) and $P$. pulmonarius (U04151).

Using some of the same sequences, Vilgalys et al. (1996) obtained the separation of P. ostreatus and $P$. pulmonarius but with a bootstrap support less than $70 \%$. The sequences of these two species differ from each other in only one base pair, and the dataset utilized in this study is insufficient to separate them. The voucher material, especially that of strain D479, which was identified as $P$. pulmonarius needs to be re-examined to confirm the identification.

The other clade includes the sequences from species with pinkish basidiomata and is divided into two subclades that each has $100 \%$ bootstrap 
support. One subclade contains sequences from Pt IV and P. djamor, and the other contains sequences from $P$. euosmus (Berk.) Sacc., $P$. flabellatus, and $P$. salmoneostramineus (according to the identifications given in GenBank). The position of Pt IV in this clade indicates that the isolate studied probably is originated from Asia, since it appears closer to the isolate from China (AY524785).

Pleurotus flabellatus has been placed in synonymy with P. djamor (Corner, 1981; Guzmán et al., 1993; Pegler 1986), and Neda et al. (1988) have demonstrated the relationship of $P$. salmoneostramineus to $P$. djamor in intercompatibility studies.

There is not much information regarding $P$. euosmus in the literature. Saccardo (1887) described the species as producing basidiomata that are white or bluish-shaded, becoming grayish. Hilber (1997) considers it to be synonymous with $P$. ostreatus, although it is considered to be a distinct species by Mycobank (www.mycobank.org). In addition, data in GenBank indicates that the sequenced strain of P. euosmus is deposited in two culture collections, ATCC and MUCL, where it is identified as P. dryinus (Pers.) P. Kummer.

The voucher specimens of these sequences need to be re-examined in order to confirm the identifications of GenBank sequences, since neither the sequence of $P$. flabellatus nor that of $P$. salmoneostramineus clusters with the sequences of $P$. djamor, and since the sequence of $P$. euosmus clusters in a clade with species that have pinkish basidiomata and its identity is not in accordance with the culture collections.

\section{ACKNOWLEDGMENTS}

The authors thank Maria Cecília Tomasi, Instituto de Botânica, for inking the illustrations; Dr. Marília Gaspar, Instituto de Botânica, for assistance with DNA amplification; Dr. Maria Helena Pelegrinelli Fungaro and Msc. Francine Matias de Paula, Universidade Estadual de Londrina, for DNA sequencing; Dr. Eduardo Pereira Cabral Gomes, Instituto de Botânica, for assistance with the statistical analyses; and the Conselho Nacional de Desenvolvimento Científico e Tecnológico (CNPq) for the support and grant to the first author.

\section{RESUMO}

Espécies de Pleurotus têm grande importância comercial e adaptabilidade para crescimento e frutificação em uma ampla variedade de resíduos agro-industriais lignocelulósicos. Neste trabalho foram testados dois substratos à base de sabugo de milho triturado, suplementados com farelo de arroz e carvão vegetal, para avaliação da cinética de crescimento micelial em tubos de ensaio e produção em sacos de polipropileno, utilizando quatro isolados comerciais. O estudo taxonômico foi realizado com a análise da morfologia dos basidiomas obtidos em cultivo e pelo seqüenciamento do gene nLSU do DNAr, para certificar a identificação taxonômica. Os isolados tiveram melhor desenvolvimento micelial em profundidade no substrato suplementado com carvão vegetal. Em relação à produção, os isolados reagiram de formas distintas em função dos substratos, sendo significativamente melhor o substrato contendo carvão. Três isolados foram identificados como $P$. ostreatus e o outro foi identificado como $P$. djamor.

\section{REFERENCES}

Bresinsky, A.; Fischer, M.; Meixner, B.; Paulus, W. (1987), Speciation in Pleurotus. Mycologia, 79, 234245.

Buchanan, P. K. (1993), Identification, names, and nomenclature of common edible mushrooms. InMushroom Biology and Mushroom Products, eds. S. Chang, J. A. Buswell, S. Chiu. Chinese University Press, Hong Kong, pp. 21-32.

Cohen, R.; Persky, L.; Hadar, Y. (2002), Biotechnological applications and potential of wooddegrading mushrooms of the genus Pleurotus. Appl. Microbiol. Biotechnol., 58, 582-594.

Colauto, N. B.; Eira, A. F. (1995), Efeito de recipientes de contenção do substrato na distribuição da produção de Pleurotus sajor-caju (Fr.) Singer. Energia na Agricultura, 10, 19-28.

Corner, E. J. H. (1981), The agaric genera Lentinus, Panus and Pleurotus, with particular reference to Malaysian species. Nova Hedwigia Beih., 69, 1-169.

Dias, E. S.; Koshikumo, E. M. S.; Schwan, R. F.; Silva, R. (2003), Cultivo do cogumelo Pleurotus sajor-caju em diferentes resíduos agrícolas. Cienc. Agrotecnol., 27, 1363-1369. 
Donini, L. P.; Bernardi, E.; Minotto, E.; Nascimento, J. S. (2006), Efeito da suplementação com farelos no crescimento in vitro de Pleurotus ostreatus em meios à base de capim-elefante (Pennisetum sp.). Arq. Inst. Biol., 73, 303-309.

Duarte, J. O. (2007), Cultivo de Milho - Mercado e comercialização. Embrapa Milho e Sorgo, Sistemas de Produção. http://www.cnpms.embrapa.br/ publicacoes/milho/ mercado.htm.

Eger, G.; Eden, G.; Wissig, E. (1976), Pleurotus ostreatus-breeding potential of a new cultivated mushroom. Theoret. Appl. Gen., 47, 155-163.

Ferreira, M. E.; Grattapaglia, D. (1996), Introdução ao uso de marcadores moleculares em análise genética. Embrapa - Cenargen, Brasília.

Guzmán, G.; Montoya, L.; Bandala, V.M.; Mata, G.; Salmones, D. (1995), Studies in the genus Pleurotus, IV. Observations on the pink forms growing in Mexico based in the interbreeding of two different strains. Mycotaxon, 53, 247-259.

Guzmán, G.; Montoya, L.; Salmones, D.; Bandala, V. M. (1993), Studies of the genus Pleurotus (Basidiomycotina), II. P. djamor in Mexico and in other Latin-American Countries, taxonomic confusions, distribution and semi-industrial culture. Crypt. Bot., 3, 213-220.

Hilber, O. (1982), Die Gattung Pleurotus. Bibl. Mycol., 87, 1-448.

Hilber, O. (1997), The genus Pleurotus (Fr.) Kummer (2). Selbstverlag, Kelheim.

Hongo, T. (1973), Notula mucologicae 12. Mem. Shiga. Univ., 23, 37-43.

Hrouda, P. (2001), Pleurotoid fungi of the family poliporaceae in the Czech Republic and Slovakia. Czech. Mycol., 53, 29-87.

Inaba, K.; Azuma, J.; Iizuka, Y.; Koshijima, T. (1983), Properties of sulfonated monosaccharides and their acceleration effect on the growth of edible mushrooms. Mokuzaigakkaishi, 29, 621-628.

Kirk, P. M.; Cannon, P. F.; Minter, D. W.; Stalpers, J. A. (2008), Dictionary of the fungi. $10 \mathrm{ed}$. CAB International, Wallingford.

Largent, D. L. (1977), How to identify mushrooms to genus I: Macroscopic Features. Mad River Press, Eureka.

Largent, D.; Johnson, D.; Watling, R. (1977), How to identify mushrooms to genus III: Microscopic Features. Mad River Press, Eureka.

Lechner, B. E.; Wright, J. E.; Albertó, E. (2004), The genus Pleurotus in Argentina. Mycologia, 96, 845858.

Maki, C. S.; Paccola-Meirelles, L. D. (2002), Characterization and cultivation of a wild mushroom species isolated in Brazil. Semina, 23, 77-82.

Mandeel, Q. A.; Al-Laith, A. A.; Mohamed, S. A. (2005), Cultivation of oyster mushrooms (Pleurotus spp.) on various lignocellulosic wastes. World $J$. Microbiol. Biotechnol., 21, 601-607.
Mikiashvili, N.; Wasser, S. P.; Nevo, E.; Elisashvili, V. (2006), Effects of carbon and nitrogen sources on Pleurotus ostreatus ligninolytic enzyme activity. World J. Microbiol. Biotechnol., 22, 999-1002.

Moda, E. M.; Horii, J.; Spoto, M. H. F. (2005), Edible mushroom Pleurotus sajor-caju production on washed and supplemented sugarcane bagasse. Sci. Agricola., 62, 127-132.

Murakami, S.; Takemaru, T. (1990), Genetic studies of Pleurotus salmoneostramineus forming albino basidiocarps. Rep. Tottori Mycol. Inst., 28, 199-204.

Neda, H.; Furukawa, H.; Miyagi, T. (1988), Two Pleurotus species from Okinawa. Proc. 32nd Ann. Meet. Mycol. Soc. Jpn., p. 51.

Pegler, D. N. (1972), Flore illustrée des champignons d'Afrique Centrale. Fasc. I, Lentineae (polyporaceae), Schizophyllaceae et espèces lentinoides et pleurotoides des Tricholomataceae. Jard. Bot. Nation, Bruxelles.

Pegler, D. N. (1977a), Pleurotus (Agaricales) in India, Nepal and Pakistan. Kew Bull., 31, 501-510.

Pegler, D. N. (1977b), A Preliminary agaric flora of East Africa. Kew Bull. Addit. Ser., 6, 1-615.

Pegler, D.N. (1986), Agaric flora of the Lesser Antilles. Kew Bull. Addit. Ser., 9, 1-668.

Pegler, D. N. (1997), Agarics of São Paulo. Royal Botanic Gardens, Kent.

Petersen, R. H.; Hughes, K. W. (1993), Intercontinental interbreeding collections of Pleurotus pulmonarius, with notes on $P$. ostreatus and other species. Sydowia, 45, 139-152.

Petersen, R. H.; Krisai-Greilhuber, I. (1996), An epitype specimen for Pleurotus ostreatus. Mycol. Res., 100, 229-235.

Ruegger, M. J. S.; Tornisielo, S. M. T.; Bononi, V. L.; Capelari, M. (2001), Cultivation of the edible mushroom Oudemansiella canarii (Jungh.) Höhn. in lignocellulosic substrates. Braz. J. Microbiol., 32, 211-214.

Saccardo, P. A. (1887). Syll. Fung., 5, 1-1146.

Segedin, B. P.; Buchanan, P. K.; Wilkie, J. P. (1995), Studies in the Agaricales of New Zealand: new species, new records and renamed species of Pleurotus (Pleurotaceae). Aust. Syst. Bot., 8, 453-482.

Singer, R. (1961), Fungi of northern Brazil. Publ. Inst. Micol., 304, 3-26.

Singer, R. (1986), The Agaricales in Modern Taxonomy. Koeltz Scientific Books, Königstein.

Sturion, G. L.; Oetterer, M. (1995), Utilização da folha da bananeira como substrato para cultivo de cogumelos comestíveis (Pleurotus spp.). Cienc. Tecnol. Aliment., 15, 194-200.

Suguimoto, H. H.; Barbosa, A.M.; Dekker, R. F. H.; Castrogomez, R. J. H. (2001), Veratryl alcohol stimulates fruiting body formation in the oyster mushroom, Pleurotus ostreatus. FEMS Microbiol. Lett., 194, 235-238. 
Swofford, D. (2003), PAUP* Phylogenetic analysis using parsimony (* and other methods), version 4 Ob10. Sinauer Associates, Sunderland, Massachusetts. Thompson, J. D.; Higgins, D. G.; Gibson, T. J. (1994), Clustal $\mathrm{W}$ : improving the sensitivity of progressive multiple sequence alignment through sequence weighting, position-specific gap penalties and weight matrix choice. Nucleic Acids Res., 22, 4673-4680.

Vilgalys, R.; Moncalvo, J. -M.; Liou, S. -R.; Volovsek, M. (1996), Recent advances in molecular systematics of the genus Pleurotus. In-Mushroom Biology and Mushroom Products, ed. D. Royse. Penn State University Press, University Park, pp. 91-101.

Vilgalys, R. ; Sun, B. L. (1994a), Ancient and recent patterns of geographic speciation in the oyster mushroom Pleurotus revealed by phylogenetic analysis of ribosomal DNA sequences. Proc. Natl. Acad. Sci., 91, 4599-4603.
Vilgalys, R.; Sun, B. L. (1994b), Assessment of species distributions in Pleurotus based on trapping or airborne basidiospores. Mycologia, 86, 270-274.

Zanetti, M.; Cazetta, J. O.; Mattos Jr., D.; Carvalho, S. A. (2003), Uso de subprodutos de carvão vegetal na formação do porta-enxerto limoeiro 'Cravo' em ambiente protegido. Rev. Bras. Frutic., 25, 508-512.

Zervakis, G.; Balis, C. (1996), A pluralistic approach in the study of Pleurotus species with emphasis on compatibility and physiology of the European morphotaxa. Mycol. Res., 100, 717-731.

Zervakis, G. I.; Moncalvo, J. -M.; Vilgalys, R. (2004), Molecular phylogeny, biogeography and speciation of the mushroom species Pleurotus cystidiosus and allied taxa. Microbiology, 150, 715-726

Received: September 22, 2008; Revised: April 08, 2009; Accepted: July 13, 2009 